\title{
The effect of high-dose lovastatin therapy on patients with acute cerebral infarction
}

\author{
Xiaoxiao Guo ${ }^{1,3}$, Cuicui Chen ${ }^{1,3}$, Jingwen Ye ${ }^{1,3}$, Kangyan Li $^{1}$, Jiexing Li ${ }^{1}$, Chengwu Cheng ${ }^{1}$, Huankun Liang ${ }^{1}$, Xipan Liu ${ }^{1}$, Shuhai Zhong', \\ Hongrui Lai ${ }^{1}$, Xiaoting Huang ${ }^{1}$, Qinglan Yang ${ }^{1}$, Licheng Zhang $^{2}$ and Laiqing $\mathrm{Li}^{1{ }^{13 *}}$ \\ ${ }^{1}$ Guangzhou Youdi Biotechnology Co., Ltd., Guangzhou, 510663, China \\ ${ }^{2}$ Cancer Center of The $88^{\text {th }}$ Hospital of People's Liberation Army, Taian, 271000, Shandong, China \\ ${ }^{3}$ Guangzhou Yijia Biotechnology Co., Ltd., Guangzhou, 510663, China
}

\begin{abstract}
Cerebrovascular disease (CVD) is the third most common cause of death worldwide and responsible for stroke and transient ischemic attack. This study aimed to investigate the clinical efficacy of high-dose lovastatin on patients with acute cerebral infarction. 150 patients with acute cerebral infarction were randomized divided into control group $(\mathrm{n}=50), 80 \mathrm{mg} / \mathrm{d}$ lovastatin $(80 \mathrm{~L})$ group $(\mathrm{n}=50)$ and $20 \mathrm{mg} / \mathrm{d}$ lovastatin $(20 \mathrm{~L})$ group $(\mathrm{n}=50)$. Control group, $80 \mathrm{~L}$ group and $20 \mathrm{~L}$ group received conventional treatment, conventional treatment together with lovastatin $80 \mathrm{mg} / \mathrm{d}$ and conventional treatment as well as lovastatin $20 \mathrm{mg} / \mathrm{d}$ respectively for 3 months. Biochemical indices, neurological deficit and plaque thickness and volume were assessed and recorded after treatment. After lovastatin treatment, the plasma levels of total cholesterol (TC), triglyceride (TG), low-density lipoprotein (LDL) were significantly decreased in $80 \mathrm{~L}$ group and $20 \mathrm{~L}$ group, and highdensity lipoprotein (HDL) were significantly increased in $80 \mathrm{~L}$ group and $20 \mathrm{~L}$ group $(\mathrm{p}<0.05)$. Moreover, lovastatin could also decrease MMP-9 and hs-CRP levels $(\mathrm{p}<0.05)$. Furthermore, improved neurological deficit were found in lovastatin treatment groups. In addition, lovastatin treatment also improved plaque states include plaque thickness and volume in $80 \mathrm{~L}$ group and $20 \mathrm{~L}$ group $(\mathrm{p}<0.05)$. What's more, high-dose lovastatin a better ability in regulated plasma lipid levels, inflammation, neurological deficit and plaque thickness and volume than low-dose of lovastatin. Lovastatin could improve acute cerebral infarction and high-dose lovastatin treatment was better than low-dose lovastatin treatment.
\end{abstract}

\section{Introduction}

Cerebrovascular disease (CVD) is one of the major causes of morbidity and mortality in industrialized countries [1-3]. CVD is the third most common cause of death worldwide and responsible for stroke and transient ischemic attack (TIA) $[4,5]$. There are about 500,000 new or recurrences stroke cases each year [6].

Lovastatin (Merck's Mevacor) is a kind of statin drug like 3-hydroxy3-methyl-glutaryl-CoA (HMG-CoA) used for lowering cholesterol in those with hypercholesterolemia to reduce risk of cardiovascular disease [7]. Lovastatin is a naturally occurring compound found in low concentrations in food such as oyster mushrooms [8], red yeast rice [9], and Pu-erh [10]. Lovastatin was beneficial in a lot of immunologic cardiovascular diseases and widely used in the world [11]. Evidences demonstrated that statins could stable plaque and improve the longterm prognosis of patients with CVD $[12,13]$. The common dose of lovastatin for CVD treatment was $20 \mathrm{mg} / \mathrm{d}$ or $40 \mathrm{mg} / \mathrm{d}[14,15]$. No reports could be found on high-dose lovastatin therapy (e.g. 80 $\mathrm{mg} / \mathrm{d}$ or $100 \mathrm{mg} / \mathrm{d}$ ) for patients with acute cerebral infarction. In this study, $80 \mathrm{mg} / \mathrm{d}$ lovastatin therapy was performed for CVD treatment. Biochemical indices, neurological deficit and adverse reactions were assessed and recorded after treatment to evaluate the effect of high-dose lovastatin therapy on patients with acute cerebral infarction.

\section{Patients and methods}

\section{Study Population}

This prospective cohort study was performed from August 2015 to October 2016. A total of 150 patients with acute cerebral infarction were admitted to the neurology department of Cancer Center of the 88
Hospital of People's Liberation Army during 72 hours of stroke (Table 1) were studied. This study was approved by Cancer Center of the 88 Hospital of People's Liberation Army (REC number: GDYY205436B), and all participants gave written informed consent.

All the patients with acute cerebral infarction were confirmed by computerized tomography (CT, SIEMENS, SOMATOM Definition AS+, Berlin, Germany) (Figure 1) and received no any other lipid, hormones, anti-inflammatory or anti-oxidant drugs during the treatment. Patients with malignant, hyperpyrexia, autoimmune disease, anaemia, malnutrition were excluded from this study. Pregnant and lactating women were also removed from this study.

\section{Treatments}

$80 \mathrm{~L}$ group and $20 \mathrm{~L}$ group were received lovastatin $80 \mathrm{mg} / \mathrm{d}$ or $20 \mathrm{mg} / \mathrm{d}$ respectively. Besides, all of subjects received conventional treatments, good nursing and medical care with attention to dehydration of intracranial pressure, brain, bowel and bladder function, control of infection, circulation improvement, and physiotherapy were provided to all patients in a comparable manner. All the treatments were performed for 3 months.

Correspondence to: Laiqing $\mathrm{Li}$, Guangzhou Youdi Biotechnology Co., Ltd., Guangzhou, 510663, China, +8613725207136; Fax: +862022056980; E-mail: 121642202@qq.com

Key words: high-dose; low-dose; lovastatin; acute cerebral infarction; computerized tomography

Received: July 26, 2017; Accepted: August 12, 2017; Published: August 17, 2017 

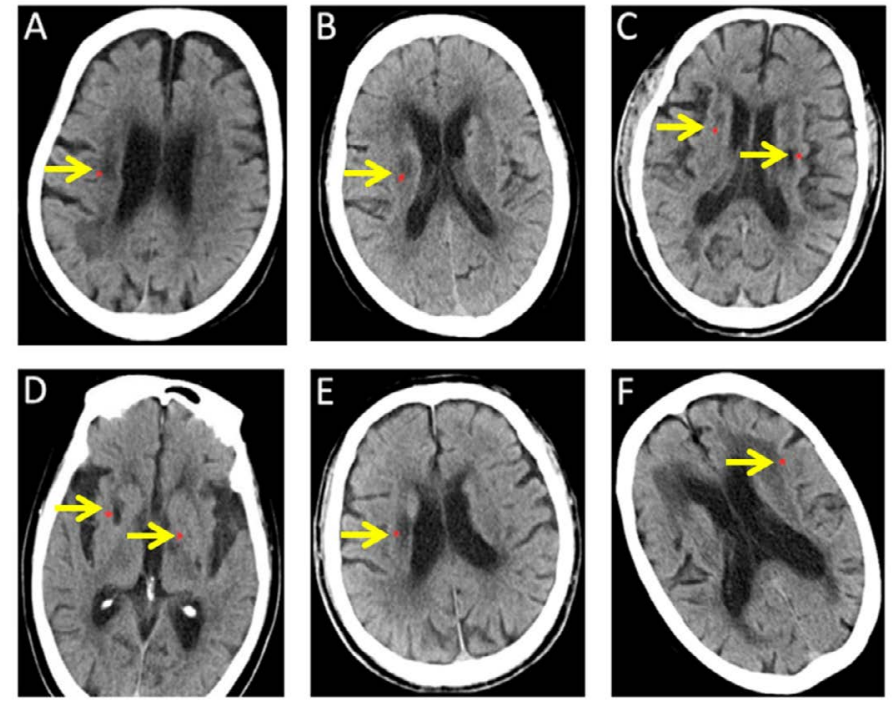

Figure 1. Patients with acute cerebral infarction were confirmed by computerized tomography (CT). (A-F): CT photos of patients with acute cerebral infarction. The arrows indicate the location of acute cerebral infarction.

Table 1. Baseline features of the study patients.

\begin{tabular}{|c|c|c|c|}
\hline Characteristic & $\begin{array}{c}\text { Control group } \\
(\mathrm{n}=50)\end{array}$ & $\begin{array}{c}\mathbf{8 0} \text { L group } \\
(\mathrm{n}=50)\end{array}$ & $\begin{array}{c}\mathbf{2 0} \text { L group } \\
(\mathrm{n}=50)\end{array}$ \\
\hline Age, years & $61.5 \pm 12.8$ & $61.1 \pm 13.7$ & $62.4 \pm 11.1$ \\
\hline Male, $\mathrm{n}(\%)$ & $33(66.0)$ & $30(60.0)$ & $31(62.0)$ \\
\hline Hypertension, $\mathrm{n}(\%)$ & $32(64.0)$ & $31(62.0)$ & $34(68.0)$ \\
\hline Diabetes, $\mathrm{n}(\%)$ & $7(14.0)$ & $9(18.0)$ & $7(14.0)$ \\
\hline Smoking, $\mathrm{n}(\%)$ & $28(56.0)$ & $30(60.0)$ & $30(60.0)$ \\
\hline Drinking, $\mathrm{n}(\%)$ & $6(12.0)$ & $8(16.0)$ & $9(18.0)$ \\
\hline Systolic pressure & $156.7 \pm 22.1$ & $156.0 \pm 21.2$ & $157.0 \pm 25.8$ \\
\hline Diastolic pressure & $88.3 \pm 12.4$ & $85.9 \pm 15.5$ & $88.8 \pm 17.5$ \\
\hline
\end{tabular}

\section{Plasma lipid and inflammatory factors analysis}

Blood for lipid and inflammatory factors analysis were collected from each group before and after treatments. Plasma was separated by centrifugation at $3,000 \mathrm{rpm}$ for $15 \mathrm{~min}$ at $4^{\circ} \mathrm{C}$ and stored at $-80^{\circ} \mathrm{C}$. TG, TC, LDL and HDL, MMP-9 and hs-CRP levels were measured by automatic biochemistry analyzer (Beckman Coulter, AU5800, South Kraemer Boulevard Brea, USA).

\section{Evaluation of neurological deficit}

Neurological deficit was conducted in control group, 80 L group and $20 \mathrm{~L}$ group according to the National Institute of Health Stoke Scale (NIHSS) criterion. NIHSS is a 15-item impairment scale used to measure stroke severity. The NIHSS includes the following domains: level of consciousness, eye movements, integrity of visual fields, facial movements, arm and leg muscle strength, sensation, coordination, language, speech and neglect. The impairment is scored on an ordinal scale ranging from 0 to 2, 0 to 3 , or 0 to 4 . Item scores are summed to a total score ranging from 0 to 42 (the higher the score, the more severe the stroke) [16].

\section{Statistical analysis}

Data are presented as mean \pm SD. Comparisons of patients' clinical parameters between groups were analyzed using the Mann-Whitney $\mathrm{U}$ test. A difference is considered significant if $\mathrm{p}<0.05$. All statistical analyses were carried out using SPSS software, version 17.0 (SPSS Inc., Chicago, IL, USA).

\section{Results and discussion}

\section{Demographic and baseline characteristics}

The clinical characteristics of the patients were summarized in Table 1 . This study involved 150 patients (94 male, 56 female) aged 48-74 years (mean $61.7 \pm 12.5$ years) with 50 cardiogenic strokes and 100 non-cardiogenic strokes. Hypertension was found in 97 patients (64.7\%) and type 2 diabetes mellitus in 23 patients (15.3\%). There were 88 patients $(58.7 \%)$ were smokers and 23 patients $(15.3 \%)$ were alcoholics. The mean systolic pressure of the patients was $156.6 \pm 23.0$, and the mean diastolic pressure of the patients was $87.7 \pm 15.1$. All the patients involved in this study were divided randomly into control group, $80 \mathrm{~L}$ group and $20 \mathrm{~L}$ group. There were no differences found about baseline characteristics among three groups $(\mathrm{p}<0.05)$. Finally, 3 patients in $80 \mathrm{~L}$ group and 2 patients in $20 \mathrm{~L}$ group were excluded.

\section{High-dose lovastatin regulated plasma lipids levels}

We measured concentration of TG, TC, LDL and HDL in control group, $80 \mathrm{~L}$ group and $20 \mathrm{~L}$ group before and after treatment to determine the effect of high-dose lovastatin plasma lipids. Results established that both low-dose and high-dose lovastatin decreased significantly plasma lipid levels including cholesterol, triglycerides, and LDL (Table 2, $\mathrm{p}<0.05)$. Moreover, cholesterol and triglycerides levels were decreased notably in $80 \mathrm{~L}$ group compared with $20 \mathrm{~L}$ group $(\mathrm{p}<0.05)$. In addition, the plasma HDL concentration was increased significantly both in $80 \mathrm{~L}$ group and $20 \mathrm{~L}$ group. However, the HDL level was higher in $80 \mathrm{~L}$ group than 20 L group $(\mathrm{p}<0.05)$.

\section{High-dose lovastatin regulated hs-CRP and MMP-9 levels}

To assess the effect of high-dose lovastatin on the inflammation, levels of hs-CRP and MMP-9 were determined in three groups. Results showed that lovastatin significantly decreased both MMP-9 and hsCRP levels (Table 3, p <0.05). Furthermore, high-dose lovastatin has a better ability in improving inflammation because of levels of MMP-9 and hs-CRP was lower in $80 \mathrm{~L}$ group $(\mathrm{p}<0.05)$.

\section{High-dose lovastatin improved neurological deficit}

Neurological deficit was evaluated and scored in control group, 80 $\mathrm{L}$ group and $20 \mathrm{~L}$ group before and after the treatment. As shown in

Table 2. Plasma lipids levels of different groups. Data are presented as mean \pm SD. ${ }^{*} p<$ 0.05 after treatment versus before treatment in $80 \mathrm{~L}$ group; $* p<0.05$ after treatment in $80 \mathrm{~L}$ group versus after treatment in $20 \mathrm{~L}$ group; ${ }^{\star} p<0.05$ after treatment versus before treatment in $20 \mathrm{~L}$ group.

\begin{tabular}{|c|c|c|c|c|c|c|}
\hline \multirow{2}{*}{} & \multicolumn{2}{|c|}{ Control group } & \multicolumn{2}{c|}{$\mathbf{8 0}$ L group } & \multicolumn{2}{c|}{$\mathbf{2 0}$ L group } \\
\cline { 2 - 7 } & $\begin{array}{c}\text { Before } \\
(\mathrm{mmol} / \mathrm{L})\end{array}$ & $\begin{array}{c}\text { After } \\
(\mathrm{mmol} / \mathrm{L})\end{array}$ & $\begin{array}{c}\text { Before } \\
(\mathrm{mmol} / \mathrm{L})\end{array}$ & $\begin{array}{c}\text { After } \\
(\mathrm{mmol} / \mathrm{L})\end{array}$ & $\begin{array}{c}\text { Before } \\
(\mathrm{mmol} / \mathrm{L})\end{array}$ & $\begin{array}{c}\text { After } \\
(\mathrm{mmol} / \mathrm{L})\end{array}$ \\
\hline $\mathrm{TG}$ & $1.6 \pm 0.5$ & $1.7 \pm 0.4$ & $1.5 \pm 0.4$ & $0.9 \pm 0.3^{* \#}$ & $1.8 \pm 0.6$ & $1.3 \pm 0.4^{\mathbf{4}}$ \\
\hline $\mathrm{TC}$ & $5.3 \pm 1.0$ & $5.2 \pm 0.9$ & $4.9 \pm 0.6$ & $3.6 \pm 0.5^{* \#}$ & $5.3 \pm 0.8$ & $4.3 \pm 0.5^{\mathbf{4}}$ \\
\hline $\mathrm{LDL}$ & $3.1 \pm 1.0$ & $3.3 \pm 1.3$ & $3.2 \pm 1.0$ & $2.4 \pm 0.7^{*}$ & $3.3 \pm 1.1$ & $2.8 \pm 0.7^{\mathbf{4}}$ \\
\hline HDL & $1.2 \pm 0.3$ & $1.2 \pm 0.2$ & $1.1 \pm 0.2$ & $1.7 \pm 0.3^{* \#}$ & $1.2 \pm 0.3$ & $1.3 \pm 0.3^{\mathbf{4}}$ \\
\hline
\end{tabular}

Table 3. Plasma MMP- 9 and hs-CRP levels of different groups. Data are presented as mean $\pm \mathrm{SD}$. ${ }^{*} p<0.05$ after treatment versus before treatment in $80 \mathrm{~L}$ group; ${ }^{*} p<0.05$ after treatment in $80 \mathrm{~L}$ group versus after treatment in $20 \mathrm{~L}$ group; ${ }^{\star} p<0.05$ after treatment versus before treatment in $20 \mathrm{~L}$ group.

\begin{tabular}{|c|c|c|c|c|c|c|}
\hline \multirow{2}{*}{} & \multicolumn{2}{|c|}{ Control group } & \multicolumn{2}{c|}{$\mathbf{8 0}$ L group } & \multicolumn{2}{c|}{20 L group } \\
\cline { 2 - 7 } & Before & After & Before & After & Before & After \\
\cline { 2 - 7 } & $(\mathrm{mmol} / \mathrm{L})$ & $(\mathrm{mmol} / \mathrm{L})$ & $(\mathrm{mmol} / \mathrm{L})$ & $(\mathrm{mmol} / \mathrm{L})$ & $(\mathrm{mmol} / \mathrm{L})$ & $(\mathrm{mmol} / \mathrm{L})$ \\
\hline CRP & $10.5 \pm 6.8$ & $8.1 \pm 5.0$ & $11.4 \pm 6.4$ & $4.5 \pm 3.7^{7 *} \#$ & $10.9 \pm 7.2$ & $5.9 \pm 3.4^{\mathbf{4}}$ \\
\hline \multirow{2}{*}{ MMP-9 } & $352.5 \pm$ & $295.2 \pm$ & $337.5 \pm$ & $191.1 \pm$ & $356.2 \pm$ & $245.6 \pm$ \\
& 90.1 & 71.3 & 104.4 & $43.7^{* \#}$ & 92.1 & $66.6^{\mathbf{4}}$ \\
\hline
\end{tabular}


Table 4, both $80 \mathrm{~L}$ and $20 \mathrm{~L}$ groups got lower scores than control group $(\mathrm{p}<0.05)$. In addition, the neurological deficit score was lower in $80 \mathrm{~L}$ group than $20 \mathrm{~L}$ group $(\mathrm{p}<0.05)$.

\section{High-dose lovastatin improved plaque thickness and volume}

We measured the anterior cerebral artery and middle cerebral artery plaque thickness and volume of patients using color Doppler ultrasound (Mindray, DC-N6, Shenzhen, China) in three groups to determine the effect of high-dose lovastatin plaque. Data indicated that lovastatin could significantly decreased plaque thickness and volume. Furthermore, the plaque thickness (Figure 2A) and volume (Figure 2B) were lower in $80 \mathrm{~L}$ group, compared with $20 \mathrm{~L}$ group $(\mathrm{p}<0.05)$.

\section{Discussion}

Lovastatin is a kind of 3-hydroxy-3-methylglutaryl coenzyme A (HMG-CoA) reductase inhibitor, which catalyzes the conversion of HMG-CoA to L-Mevalonate, leading to the blockade of cholesterol biosynthesis [17]. Statins would also inhibit the biosynthesis of isoprenoid intermediates such as geranyl and farnesyl pyrophosphate, and then affect the posttranslational prenylation of several important cell-signaling proteins during immune responses $[18,19]$. Therefore, lovastatin has been shown to have antitumor potential in many different cell lines [20,21].

Atherosclerosis is a systemic disease with high level of lipid and responsible for major clinical events, such as stroke and acute cerebral infarction [22-24]. Atherosclerosis is the principal cause of death in the USA, Europe, and parts of Asia [25,26]. Lovastatin was an effective lipid-lower drug that was used extensively in many medical practices [27-29]. Lovastatin has been shown to reduce the progression of coronary atherosclerosis and clinical trials indicated that treatment with lovastatin could reduce the morbidity and mortality of CVD [30]. In this study, we find that low-dose and high-dose lovastatin regulated plasma lipids levels including significantly decreased cholesterol, triglycerides, and LDL levels and dramatically increased HDL level. Moreover, high-dose lovastatin could strengthen this effect compared with low-dose of lovastatin.

Table 4. Neurological deficit scores of different groups. Data are presented as mean $\pm \mathrm{SD}$ $" p<0.05$ after treatment versus before treatment in $80 \mathrm{~L}$ group; $" p<0.05$ after treatment in $80 \mathrm{~L}$ group versus after treatment in $20 \mathrm{~L}$ group; ${ }^{\mathbf{\Delta}} p<0.05$ after treatment versus before treatment in $20 \mathrm{~L}$ group.

\begin{tabular}{|c|c|c|}
\hline Group & Before & After \\
\hline Control group & $11.58 \pm 3.77$ & $8.85 \pm 0.75$ \\
\hline 80 L group & $11.14 \pm 3.52$ & $7.02 \pm 0.51^{\text {*\# }}$ \\
\hline 20 L group & $11.53 \pm 3.92$ & $7.74 \pm 0.57^{\mathbf{}}$ \\
\hline
\end{tabular}

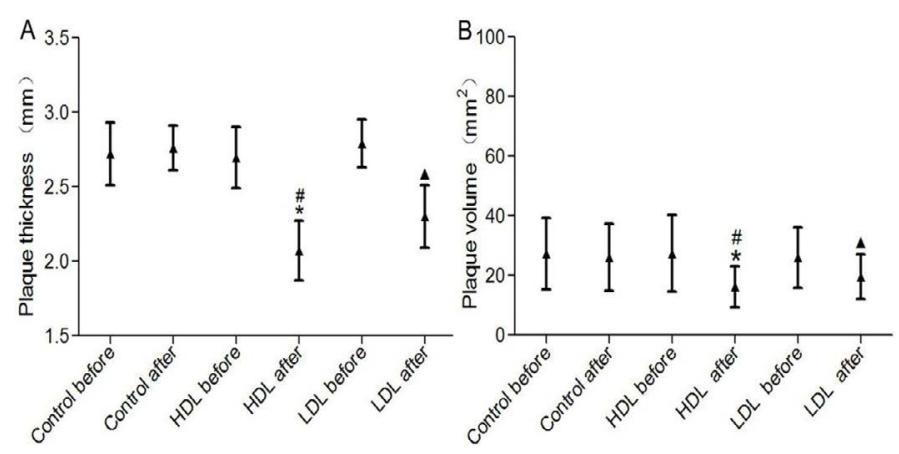

Figure 2. Plaque thickness and volume. Data are presented as mean \pm SD. " $p<0.0580 \mathrm{~L}$ after versus $80 \mathrm{~L}$ before; ${ }^{\#} p<0.0580 \mathrm{~L}$ after versus $20 \mathrm{~L}$ after; ${ }^{\star} p<0.0520 \mathrm{~L}$ after versus $20 \mathrm{~L}$ before.
Clinical further studies demonstrated that lovastatin not only regulated plasma lipids concentrations, but also improved inflammation response, such as enhances anti-inflammation effect in CVD [31-33]. Hs-CRP and MMP-9, two major inflammation markers, were elevated significantly in lovastatin treated patients of this study. In addition, the plasma hs-CRP and MMP-9 levels were higher in 80 L group than 20 L group.

Additional studies shown that, besides the lipid-lower effect, at the same time lovastatin could stabilize the atherosclerotic plaque and have beneficial effects on cerebral circulation and brain parenchyma during ischemic stroke and reperfusion [34]. We measured the plaque thickness and volume of patients in three groups and found that lovastatin could significantly decreased plaque thickness and volume. Furthermore, the plaque thickness and volume were lower in $80 \mathrm{~L}$ group, compared with 20 L group.

The common dose of lovastatin for CVD treatments was $20 \mathrm{mg} / \mathrm{d}$ or $40 \mathrm{mg} / \mathrm{d}$. However, very few reports were found on high-dose (e.g. $80 \mathrm{mg} / \mathrm{d}$ ) lovastatin therapy for patients with acute cerebral infarction. In this study, $80 \mathrm{mg} / \mathrm{d}$ lovastatin was used to assess its effect on CVD. We found that high-dose lovastatin could significantly improve plasma lipids levels, enhances anti-inflammation effect and decreased plaque thickness and volume than low-dose of lovastatin. In addition, no adverse effect was found in $80 \mathrm{~L}$ group.

In conclusion, this prospective, randomized, placebo-controlled trial demonstrated that treatment with $80 \mathrm{mg}$ lovastatin per day has a better therapeutic effect on patients with acute cerebral infarction than $20 \mathrm{mg}$ lovastatin per day. These results support the initiation of lovastatin treatment after a stroke or TIA.

\section{Acknowledgments}

This study was funded by the Guangdong Province Science and Technology Project (No. 2016A010119067); and the Shandong Province Medical and Health Technology Development Project (No. 2016WS0725).

\section{Reference}

1. Lee MS, Shlofmitz E, Kaplan B, Shlofmitz R (2016) Percutaneous Coronary Intervention in Severely Calcified Unprotected Left Main Coronary Artery Disease: Initial Experience With Orbital Atherectomy. J Invasive Cardiol 28: 147-150. [Crossref]

2. Idris I, Thomson GA, Sharma JC (2006) Diabetes mellitus and stroke. Int J Clin Pract 60: 48-56. [Crossref]

3. Blanco-Colio LM, Martín-Ventura JL, de Teresa E, Farsang C, Gaw A, et al. (2007) Elevated ICAM-1 and MCP-1 plasma levels in subjects at high cardiovascular risk are diminished by atorvastatin treatment. Atorvastatin on Inflammatory Markers study: a substudy of Achieve Cholesterol Targets Fast with Atorvastatin Stratified Titration. Am Heart $J$ 1: 881-888. [Crossref]

4. McNeill E, Channon KM, Greaves DR (2010) Inflammatory cell recruitment in cardiovascular disease: murine models and potential clinical applications. Clin Sci (Lond) 118: 641-655. [Crossref]

5. Greenland P, Knoll MD, Stamler J, Neaton JD, Dyer AR, et al. (2003) Major risk factors as antecedents of fatal and nonfatal coronary heart disease events. JAMA 290: 891-897. [Crossref]

6. Khot UN, Khot MB, Bajzer CT, Sapp SK, Ohman EM, et al. (2003) Prevalence of conventional risk factors in patients with coronary heart disease. JAMA 290: 898-904 [Crossref]

7. Yang T, Yao H, He G, Song L, Liu N, et al. (2016) Effects of Lovastatin on MDAMB-231 Breast Cancer Cells: An Antibody Microarray Analysis. J Cancer 7: 192-199. [Crossref]

8. Gunde-Cimerman N, Cimerman A (1995) Pleurotus fruiting bodies contain the inhibitor of 3-hydroxy-3-methylglutaryl-coenzyme A reductase-lovastatin. Exp Mycol 19: 1-6. [Crossref] 
9. Liu J, Zhang J, Shi Y, Grimsgaard S, Alraek T, et al. (2006) Chinese red yeast rice (Monascus purpureus) for primary hyperlipidemia: a meta-analysis of randomized controlled trials. Chin Med 1: 4. [Crossref]

10. Zhao ZJ, Pan YZ, Liu QJ, Li XH (2013) Exposure assessment of lovastatin in Pu-erh tea. Int J Food Microbiol 164: 26-31. [Crossref]

11. Schönbeck U, Libby P (2004) Inflammation, immunity, and HMG-CoA reductase inhibitors: statins as antiinflammatory agents? Circulation 109: II18-26. [Crossref]

12. Seljeflot I, Tonstad S, Hjermann I, Arnesen H (2002) Reduced expression of endothelial cell markers after 1 year treatment with simvastatin and atorvastatin in patients with coronary heart disease. Atherosclerosis 16: 179-185. [Crossref]

13. Tousoulis D, Bosinakou E, Kotsopoulou M, Antoniades C, Katsi V, et al. (2006) Effects of early administration of atorvastatin treatment on thrombotic process in normocholesterolemic patients with unstable angina. Int J Cardiol 106: 333-337. [Crossref]

14. Zheng QL, Zhong JH, Zhang GX (2010) Effect of lovastatin on serum concentration of adiponectin in patients with acute myocardial infarction. China J Mod Med 16: 2523-2525.

15. Yin JJ, Lin F, Wang GL (2009) Effect of Lovastatin on carotid atherosclerotic plaques, levels of blood lipid and serum C-reactive protein. J Clin Neurol 6: 458-460.

16. Kwah LK, Diong J (2014) National Institutes of Health Stroke Scale (NIHSS). J Physiother 60: 61.

17. Zhao N, Dong Q, Qian C, Li S, Wu QF, et al. (2015) Lovastatin blocks Kv1.3 channel in human T cells: a new mechanism to explain its immunomodulatory properties. $\mathrm{Sci}$ Rep 5: 17381-17395.

18. Bu DX, Griffin G, Lichtman AH (2011) Mechanisms for the anti-inflammatory effects of statins. Curr Opin Lipidol 22: 165-170. [Crossref]

19. Chow SC (2009) Immunomodulation by statins: mechanisms and potential impact on autoimmune diseases. Arch Immunol Ther Exp (Warsz) 57: 243-251. [Crossref]

20. Altwairgi AK (2015) Statins are potential anticancerous agents (review). Oncol Rep 33: 1019-1039. [Crossref]

21. Zeiser R, Maas K, Youssef S, Dürr C, Steinman L, et al. (2009) Regulation of different inflammatory diseases by impacting the mevalonate pathway. Immunology 127: 18-25. [Crossref]

22. Virmani R, Kolodgie FD, Burke AP, Farb A, Schwartz SM (2000) Lessons from sudden coronary death: a comprehensive morphological classification scheme for atherosclerotic lesions. Arterioscler Thromb Vasc Biol 20: 1262-1275. [Crossref]
23. Stary HC, Chandler AB, Dinsmore RE, Fuster V, Glagov S, et al. (1995) A definition of advanced types of atherosclerotic lesions and a histological classification of atherosclerosis. A report from the Committee on Vascular Lesions of the Council on Arteriosclerosis, American Heart Association. Circulation 9: 1355-1374. [Crossref]

24. Falk E, Shah PK, Fuster V (1995) Coronary plaque disruption. Circulation 92: 657671. [Crossref]

25. Pennell DJ, Underwood SR, Manzara CC, Swanton RH, Walker JM, et al. (1992) Magnetic resonance imaging during dobutamine stress in coronary artery disease. $\mathrm{Am}$ J Cardiol 70: 34-40. [Crossref]

26. Sever PS, Dahlöf B, Poulter NR, Wedel H, Beevers G, et al. (2003) Prevention of coronary and stroke events with atorvastatin in hypertensive patients who have average or lower-than-average cholesterol concentrations, in the Anglo-Scandinavian Cardiac Outcomes Trial--Lipid Lowering Arm (ASCOT-LLA): a multicentre randomised controlled trial. Lancet 361: 1149-1158. [Crossref]

27. Nielsen SF, Nordestgaard BG, Bojesen SE (2013) Statin use and reduced cancer-related mortality. N Engl J Med 368: 576-577. [Crossref]

28. McGlynn KA, Hagberg K, Chen J, Graubard BI, London WT, et al. (2015) Statin use and risk of primary liver cancer in the Clinical Practice Research Datalink. J Natl Cancer Inst: 107. [Crossref]

29. Ampuero J, Romero-Gomez M (2015) Prevention of hepatocellular carcinoma by correction of metabolic abnormalities: Role of statins and metformin. World J Hepatol 7: 1105-1111. [Crossref]

30. Amarenco P, Labreuche J, Lavallée P, Touboul PJ (2004) Statins in stroke prevention and carotid atherosclerosis: systematic review and up-to-date meta-analysis. Stroke 3: 2902-2909. [Crossref]

31. Goldstein LB, Amarenco P, Bogousslavsky J, Callahan AS, Hennerici MG, et al. (2004) Statins for secondary stroke prevention in patients without known coronary heart disease: the jury is still out. Cerebrovasc Dis 18: 1-2. [Crossref]

32. Lunder M, Janic M, Ziberna L, Drevensek G, Sabovic M (2012) A low-dose atorvastatin and losartan combination directly improves aortic ring relaxation and diminishes ischaemic-reperfusion injury in isolated rat hearts. Med Sci Monit 18: BR366-BR374 [Crossref]

33. Jain MK, Ridker PM (2005) Anti-inflammatory effects of statins: clinical evidence and basic mechanisms. Nat Rev Drug Discov 4: 977-987. [Crossref]

34. Moonis M, Kane K, Schwiderski U, Sandage BW, Fisher M (2005) HMG-CoA reductase inhibitors improve acute ischemic stroke outcome. Stroke 36: 1298-1300. [Crossref]

Copyright: (C2017 Guo X. This is an open-access article distributed under the terms of the Creative Commons Attribution License, which permits unrestricted use, distribution, and reproduction in any medium, provided the original author and source are credited. 